\title{
Grotian Moments: An Introduction
}

\author{
Tom Sparks \\ Max Planck Institute for Comparative Public Law and International Law, \\ Heidelberg, Germany \\ sparks@mpil.de \\ Mark Somos \\ Max Planck Institute for Comparative Public Law and International Law, \\ Heidelberg, Germany \\ somos@mpil.de
}

'In the contemporary age of highly developed techniques of communication and information, the formation of a custom through the medium of international organisations is greatly facilitated and accelerated; the establishment of such a custom would require no more than one generation of even far less than that.'

'since it is in my power/ To o'erthrow law, and in one self-borne hour, / To plant and o'erwhelm custom.'2

'I remember yesterday,' said Wen thoughtfully. 'But the memory is in my head now. Was yesterday real? Or is it only the memory which is real? Truly, yesterday I was not born.'3

This special issue focuses on Grotian Moments, rapid crystallisations of new rules and doctrines of customary international law. It is a concept with several contrasting but closely connected definitions which, taken together, form a reasonably coherent semantic range of accepted use. In harmony with Grotiana's mission to explore the Grotian tradition while paying close

1 South West Africa, Second Phase, Judgment, ICJ Reports 1996, Dissenting opinion of Judge Tanaka, p. 293.

2 William Shakespeare, The Winter's Tale, ed. by John Pitcher (London: Arden Shakespeare, 2010), IV.1.II.7-9.

3 Terry Pratchett, Thief of Time (London: Transworld Publishers, 2007), p. 9. 
attention 'to Grotius' relevance for present-day thinking about world problems', our aim is to combine historical and analytical approaches to the competing definitions; identify overlaps and narrow the acceptable semantic range when definitional disagreements are superficial; and bring out the plurality of autonomously cogent and self-coherent uses when disagreements prove substantial and informative.

The term, 'Grotian Moment', has become a familiar one to international lawyers. Since its first use by Richard Falk in 1985, it has been doubted, denigrated, lauded, proclaimed, and applied in various ways by different actors, and in different settings. ${ }^{4}$ Though numerous commentators have questioned or denied whether it can bear any explanatory potential, it has also been given voice by key actors in the field. In 1994 the then-UN Secretary-General, Boutros Boutros-Ghali, described the opportunity to expand the international juridical order as a Grotian Moment, for example. ${ }^{5}$ And the concept gained practical legal relevance in 2009, when the Prosecution of the Extraordinary Chambers in the Courts of Cambodia characterised the Nuremberg Tribunals as a Grotian Moment, ${ }^{6}$ a move which some involved with the drafting of that memorandum credit (at least in part) with the acceptance by the Chambers of the concept of joint criminal enterprise in relation to international crimes. ${ }^{7}$ Grotian moments have been claimed in relation to the continental shelf, space, Tadić, the invasion of Iraq, Assad's use of chemical weapons in Syria, and distinguished from other terms of art such as instant custom and constitutional moments. ${ }^{8}$ Yet there remains a great deal of ambiguity over the semantic range of the concept, its application in practice, and what - or even whether-legal consequences eventuate from the designation of an event as a 'Grotian Moment'.

4 See Edward Jones Corredera, 'Why International Lawyers Measure Time with a Telescope: Grotian Moments \& Richard Falk's Histories of the Future', infra.

5 Boutros Boutros-Ghali, 'A Grotian Moment'. Fordham International Law Journal 18:5 (1994), 16o9-1616.

6 See Michael Scharf, 'Grotian Moments: The Concept', infra. In a sense 'Grotian' signals a bid for higher status in the hierarchy of sources of law within customary international law, akin to the historical process that has ascribe and continues to ascribe the rank of 'jus cogens' to certain legal norms. Dinah Shelton, Jus Cogens (Oxford: Oxford University Press, 2021), pp. 7-8.

7 See Scharf, 'Grotian Moments: The Concept', infra, and further: Michael Scharf, 'Seizing the "Grotian Moment": Accelerated Formation of Customary International Law in Times of Fundamental Change', Cornell Journal of International Law 43:3 (2010), 439-469, p. 468.

8 Instant custom: Bin Cheng, 'United Nations Resolutions on Outer Space: "Instant” Customary International Law?", The Indian Journal of International Law 5 (1965), 23-112. 


\section{Names, Concepts, and Praxis: an Uncertain Relationship}

Naming things and understanding them are loosely related processes at best. We used to think we knew what gravity was until Newton changed our minds, before Einstein changed our minds again. We know we don't know what 'dark matter' or 'quantum entanglement' are, but we choose and use these terms to describe yet-unknown causes of partly observable effects. Some names, such as personal given names, permanently affix words to things. Others are heuristic devices that function as placeholders understood to assist discovery and evolving definition. 'Grotian Moments' ambitiously combines two heuristic devices: the figure of Grotius and the analogy of moments.

Hugo Grotius (1583-1645) is commonly called the father of modern international law. In addition to De iure belli ac pacis, widely regarded as the first systematic international law treatise, his defence of the right to free trade in Mare liberum has been described as the founding statement of capitalism, liberalism, imperialism, and a few other -isms besides. For over four centuries, Grotius has been and continues to be used and recycled at tribunals and by scholars as a source and authority in international law, not always with precise or any reference to his arguments or works. ${ }^{9}$

Searching for defining moments for the purpose of progressively exploring, defining or teaching a process is almost as attractive a pursuit as the search for father figures. In international law alone, scholars have posited Machiavellian, Gentilian, Vitorian, Grotian, Seldenian and Marbury moments. ${ }^{10}$

The device of 'moments' is particularly significant for Grotian Moments because they occupy the domain of customary international law, where the time conditions for something to become custom and be accepted as custom have been a constant and perhaps genuinely inexhaustible source of debate.11

9 Mark Somos, 'Open and Closed Seas: The Grotius-Selden Dialogue at the Heart of Liberal Imperialism', in: Empire and Legal Thought: Ideas and Institutions from Antiquity to Modernity, ed. by Edward Cavanagh (Leiden: Brill, 2020), pp. 322-61.

10 Machiavellian: John G.A. Pocock, The Machiavellian Moment: Political Thought and the Atlantic Republican Tradition (Princeton: Princeton University Press, 1975). Gentilian: Benedict Kingsbury and Benjamin Straumann, 'Introduction', in: The Roman Foundations of the Law of Nations: Alberico Gentili and the Justice of Empire, ed. by Kingsbury and Straumann (Oxford: Clarendon, 2010). Vitorian: Antony Anghie, 'Francisco De Vitoria and the Colonial Origins of International Law', Social and Legal Studies 5:3 (1996), 321-36. Seldenian: Mark Somos, 'Selden's Mare clausum: The Secularisation of International Law and the Rise of Soft Imperialism', Journal of the History of International Law 14:2 (2012), 287-330. Marbury: Steven Arrigg Koh, 'Marbury Moments', Columbia Journal of Transnational Law 54 (2015), 116-63, esp. sections III-V.

11 See, among many others, Jörg Kammerhofer, 'Uncertainty in the Formal Sources of International Law: Customary International Law and Some of Its Problems' European 
The International Court of Justice, in its judgement in the North Sea Continental Shelf Cases gave what is now taken to be the definitive statement of what constitutes customary international law. Custom is formed of two elements: State practice and opinio iuris; the belief in the legal nature of the rule. ${ }^{2}$ The practice concerned must be 'extensive and virtually uniform, ${ }^{13}$ and moreover must 'amount to a settled practice. ${ }^{14}$ How long, though, does it take for a practice to 'settle'? Does custom form after time immemorial, a century, or can it emerge overnight? Are there different time spans depending on the subject matter, or on the significance of the rule; and if there are multiple temporal standards, how are they harmonised in practice, for instance whenever legal claims based on State practice and opinio iuris on immovably defended sovereign immunity meet claims for unstoppably emerging customary international law responsibility for war crimes?

\section{Entangled Definitions}

In this special issue we did not seek to impose a definition or understanding of 'Grotian Moment' on the various contributors, and neither is it our goal to produce a single, cohesive description as the outcome of the engagements herein. Rather, the at least doubly heuristic nature of 'Grotian Moments' is one reason why we are content and grateful to foster a conversation without aiming for unanimity. If this volume moves us toward a better understanding of the uses and limits of the phrase that describes a well-documented phenomenon (and we believe this collection does that), we are happy. Another obvious reason not to insist on adherence to a singular detailed definition concerns the benefits of engageable challenges by colleagues, and the relative futility of a strict demarcation that would put, for example, Continental Shelf in the Grotian Moments set; the use of force in self-defence against non-state actors since the Syrian conflict in the non-Grotian Moment set; and the Grotian Moment character of

Journal of International Law 15:3 (2004), 523-553; Stefan Talmon, 'Determining Customary International Law: The ICJ's Methodology between Induction, Deduction and Assertion', European Journal of International Law 26:2 (2015), 417-443; B.S. Chimni, 'Customary International Law: A Third World Perspective', American Journal of International Law 112:1 (2018), 1-46; Monica Hakimi, 'Making Sense of Customary International Law', Michigan Law Review 118:8 (2020), 1487-1538; Jean d'Aspremont, The Discourse on Customary International Law (Oxford: Oxford University Press, 2021).

12 North Sea Continental Shelf, Judgment, ICJ Reports 1969, 3, at [77].

13 North Sea Continental Shelf, at [74].

14 North Sea Continental Self, at [77]. 
UNGA Resolutions concerning terrorism financing into the ab ovo undiscussable set of international legal developments. Advancing a conversation does not require ending it; nor is it always a sign of woolly thinking to admit the validity of plural perspectives. There is, too, merit in protecting a space for constructive dialogue, of seeking rather than pretending to explain a phenomenon, which offers arguments against insisting on an over-rigorous definition that this volume has in common with many similar endeavours. ${ }^{15}$

\section{The Customary Problem}

The third and, for present purposes, final reason to prefer this collection to provide a fluid but improving definition of Grotian Moments, instead of a rapidly crystallising one, is unique to this volume. This reason is that conceptual and practical imprecision is in part a bug, but mainly a feature of Grotian Moments. This is because Grotian Moments denote a process in customary international law, which is in itself at least as imprecise and fluid as Grotian Moments are, and arguably far more so. ${ }^{16}$ According to the ILC, 'customary international law as a source inherently denies exact formulations.' ${ }^{17}$ Kolb notes that even a general principle such as good faith cannot correct the legal uncertainty inherent to customary international law, since custom reflects spontaneously emerging and inevitably disputable norms. ${ }^{18}$ In addition to its inherent resistance to exact formulations, Thirlway begins and ends his book on the sources of international law by drawing attention to the difficulties of identifying widely agreeable custom.

First, being a more flexible concept and process than treaty law, it is continually being revised and re-examined in practice and, significantly, in judicial decisions; and secondly, it is the most fertile field for the enunciation of new theories of how it operates, or how it ought to operate. [...]

15 E.g. Hent Kalmo and Quentin Skinner (eds.), Sovereignty in Fragments: The Past, Present and Future of a Contested Concept (Cambridge: Cambridge University Press, 2010).

16 Though tangentially, it is relevant to note that jus cogens norms are widely regarded as indeterministic legal fiction with a primarily heuristic character that is hardly more friendly to authoritative definitions or content. Shelton, Jus Cogens, p. 1.

17 Fifth Report of the Special Rapporteur on Identification of Customary International Law, A/ CN4/717, para. 20. Schabas agrees: '[b]y its very nature, custom eludes codification.' William A. Schabas, The Customary International Law of Human Rights (Oxford: Oxford University Press, 2021).

18 Robert Kolb, Good Faith in International Law (Hart: Oxford, 2017), pp. 81-84; Talmon, 'Determining Customary International Law'. 
There are intellectual puzzles, such as the development of custom, which has to exist, in order to be believed to exist, in order to exist. ${ }^{19}$

Thirlway also remarks on numerous logical fallacies. By divorcing opinio iuris from State practice, customary international law watchers are in fact looking for opinio opinionis iuris. ${ }^{20}$ Moreover, how can opinio iuris serve to establish customary international law that does not yet exist? 'Or must we say that the erroneous belief that there is an established practice is sufficient to contribute to bringing that practice into existence?'21

Just as confused as the opinio iuris problem is the temporal element in custom's formation. Here, the idea of the Grotian Moment finds some tangential support in the general discourse on formation, which centres around the 'crystallisation' of a norm. It is a term-or perhaps a metaphor?-routinely employed by the ICJ, for example in its recent decision in the Chagos Archipelago Advisory Opinion. There the Court noted that in order to answer the question put to it, 'the Court must ascertain when the right to self-determination crystallized as a customary rule binding on all States. ${ }^{22}$ It concluded that in the case of the self-determination norm in question, the customary rule emerged from the decolonisation practice of the 1960s, and it laid particular emphasis on the UN General Assembly's Resolution 1514(XV), the Declaration on the Granting of Independence to Colonial Territories and Peoples. That resolution, it said, 'represents a defining moment in the consolidation of State practice on decolonization. ${ }^{23}$

Crystallisation is referenced, too, in the ILC's Draft Conclusions on the Identification of Customary International Law, prepared under the guidance of Special Rapporteur Sir Michael Wood. ${ }^{24}$ Conclusion 11 refers to the possibility that the conclusion of a treaty may 'le[a]d to a crystallization of a rule', while crystallisation is given a key place in the functioning of the persistent objector

19 Hugh Thirlway, The Sources of International Law (2nd ed., Oxford: Oxford University Press, 2019), Preface, p. v; and 'A Brief Note in Conclusion', p. 238.

20 Thirlway, Sources, p. 69. An attempt to resolve this regression: Anthea Roberts, 'Traditional and Modern Approaches to Customary International Law: A Reconciliation', American Journal of International Law 95 (2001), 757-91.

21 Thirlway, Sources, p. 85. For further paradoxes see pp. 89, 94, 96, 224.

22 Legal Consequences of the Separation of the Chagos Archipelago from Mauritius in 1965, Advisory Opinion, ICJ Reports 2019, p. 95, at [148].

23 Chagos Archipelago, at [150].

24 Sir Michael Wood also contributes to this special issue, together with Omri Sender. See 'Between "Time Immemorial" and "Instant Custom": The Time Element in Customary International Law', infra. 
rule (Conclusion15), the commentary to which notes that in order persistently to object, the State in question 'must express its opposition before a given practice has crystallized into a rule. ${ }^{25}$

Inherent in the idea of crystallisation is that of a change of state. That a rule becomes: over the course of a day, year or decade a practice transitions from being a habit to being a demand of the legal order. Coupled with the rule against retroactivity - that an action must be judged according to international law at the time at which it occurred - the crystallisation discourse inevitably leads to a push to identify moments of change. When precisely, we ask, did the rule emerge? Seen in this light, Grotian Moments may be little more than another kind of crystallisation moment.

Yet the crystallisation question is far from a simple one. Its impracticalities and paradoxes have been extensively discussed, ${ }^{26}$ and Jutta Brunnée and Stephen Toope have recently advocated a move away from the language of crystallisation entirely, proposing a theoretical model whereby custom gels:

'although the diffuse, fluid nature of the customary law-making process does not negate promulgation and clarity, it does make it harder to identify the precise point at which law arises than does treaty-making with its emphasis on written terms and detailed rules on entry-into-force. The prevailing metaphor of "crystallisation" is therefore misleading, not only because it suggests an easily identifiable moment when custom has come into being, but also because it masks the dynamism of norm-maintenance and further development. Like all law, customary international law gels; it does not crystallise. ${ }^{27}$

Within this diffuse and divergent discourse, what role do Grotian Moments play? In the eyes of its advocates, Grotian Moments help to complete the complex jigsaw puzzle that is customary law. ${ }^{28}$ By acknowledging the catalysing effect that events external to the legal system (narrowly construed) may have on law, the concept helps to explain the unusually rapid speed at which some

25 Draft Conclusions on the Identification of Customary International Law with Commentaries, Yearbook of the International Law Commission 2018, vol. II, Part Two, at Conclusion 11(1)(b), Commentary to Conclusion 15 , para 5 .

26 See e.g. Jan Klabbers, International Law (3rd ed., Cambridge: Cambridge University Press, 2021), p. 331; Thirlway, Sources, pp. 149, 159; Talmon, 'Determining Customary International Law'; Hakimi, 'Making Sense of Customary International Law'.

27 Jutta Brunnée and Stephen J. Toope, 'International Law and the Practice of Legality: Stability and Change', Victoria University of Wellington Law Review 49:4 (2018), 429-45.

28 See, in particular in this collection, Scharf, 'Grotian Moments: The Concept', infra. 
customary rules seem to emerge both in legal and sociological terms. In the softer versions of this thesis, and indeed in the conceptions of some of those critical of the concept, 'Grotian Moments' are understood to describe a legal phenomenon but as without legal effect in themselves. ${ }^{29}$ Even if one accepts this point, however, one could still cogently counter that it verges on a distinction without a difference. There are powerful arguments that declarations and invocations of ius cogens norms derive their legal effect from their symbolic and rhetorical use. For courts to say that the prohibition of slavery or torture is morally abhorrent and has always been ius cogens is to engage in bait-andswitch like a magician at a party for children particularly good at suspending disbelief. ${ }^{30}$ To recognise that the line between declarative and expressive functions is at least on occasion blurry or negotiable in international law is not to deny that the line exists; and the comparison between the function of ius cogens and that of Grotian Moments illustrates the extent to which insisting that the latter has no legal effect is to miss, to some extent, the actual operation of international law. After all, the concept of Grotian Moments arguably had a legal impact on JCE before the Cambodia tribunal. Was the effect of Grotian Moments in this case less 'legal' than the effect ius cogens had when the ICJ invoked it in Armed Activities to characterise the prohibition of genocide while it simultaneously noted that its own jurisdiction was unaffected by the involvement of a ius cogens norm in the case, and remained wholly subject to States' consent? ${ }^{31}$

We suggest that the many indeterminacies of customary international law may be neither accidental nor solvable, and perhaps above all the question over customary law's interaction with time. It is a feature, not a bug. Efforts, such as the ILC's and Schabas', comprehensively to survey State practice and opinio iuris to establish customary international law are laudable and useful, perhaps even potentially authoritative, but they will not 'fix' customary international law not only because it evolves, but also because it needs anointed professionals to create widely accepted time. Quantum physics suggests that

29 See Dire Tladi, 'Grotian Moments and Peremptory Norms of General International Law: Friendly Facilitators or Fatal Foes?', infra. Sender and Wood, 'Between "Time Immemorial” and "Instant Custom": The Time Element in Customary International Law', infra. Also Robert Volterra, Review of Michael P. Scharf, Milena Sterio and Paul R. Williams, The Syrian Conflict's Impact on International Law, Grotiana 42:1 (2021), 167-72. Andrea Bianchi, 'Human Rights and the Magic of Jus Cogens', European Journal of International Law 19:3 (2008), 491-508; Anthony D'Amato, 'It's a Bird, It's a Plane, It's Jus Cogens!' Connecticut Journal of International Law 6(1) (1990) 1-6.

$3^{1}$ Armed Activities on the Territory of the Congo (Congo $v$ Rwanda), Judgment on Preliminary Objections. 
Newton invented, not discovered, objective time; and, moreover, that his innovation had little to do with underlying physical realities. Physics now understands bodies to carry their own cloud of quantum probabilities and that when they meet, their probability clouds are collapsed to create a time that is specific to that encounter. Clocks run faster on a mountain than at the seaside and bodies in diverging motion will never share time, because time is relational. ${ }^{32}$ The elasticity of time in the Grotian Moments concept is particularly apt in light of these new insights from quantum physics, and also well-suited for the thus far unsettled puzzles and paradoxes that legal scholars have identified in the time factor in customary international law.

\section{Historical Moments}

This collection sheds new light on these questions because it marries the historical and contemporary perspectives on Grotian Moments, and thereby expands the possible set of cases that qualify as Grotian Moments from the reasonably well-established and limited instances, commonly accepted in the literature and starting with Nuremberg, to include, among others, the publication of $I B P$ itself in 1625 (with a substantially revised edition in 1631), and the near-simultaneous English attempt to re-engineer Magna Carta to serve as a form of universal declaration of human rights. One of the assets legal history brings to this marriage is therefore an improved distinction between Grotian Moments as they occur, relatively quickly compared to the sedimentation rate of 'non-Grotian' customary international law, and between their recognition as Grotian Moments. (Though beyond the scope of this methodological discussion, should a reader infer that the legal history perspective is similarly revelatory for current theorisations and applications of customary international law writ large, the editors would not protest.)

It is an all-too-rarely doubted axiom of legal historiography that the 1625 appearance of Grotius' De iure belli ac pacis (IBP) ushered in modern international law. ${ }^{33}$ Plato, Machiavelli, and others before Grotius have claimed that they founded or re-founded a discipline, but few of them were taken at their word. Yet many of Grotius' contemporaries acknowledged that he had done

32 See the smurf illustrations in Carlo Rovelli, The Order of Time (2017; English tr. London: Penguin, 2019).

33 Tamar Herzog, A Short History of European Law: The Last Two and a Half Millennia (Cambridge: Harvard University Press 2019), pp. 16o-1. Somos, 'Open and Closed Seas'. 
something new; they disagreed only about where his originality lay. Some valued $I B P$ for its lucid systematisation of legal doctrine and irenic potential. In the middle of the Thirty Years' War, one of the most traumatic conflicts in European history, $I B P$ removed religion from international law, offering warring factions a common moral foundation, procedural standards, and rules for negotiation. ${ }^{34}$ Others, including Christian Thomasius and Jean Barbeyrac, touted $I B P$ as the first systematic treatise on international law that cut through millennia of deliberate obfuscation and distortion by power-hungry, manipulative Aristotelians, ancient Romans and modern Catholics. ${ }^{35}$

In terms of the disciplinary genealogy and professionalisation, the first chair in public international law was established to expound $I B P$, and given to Samuel Pufendorf in Heidelberg. For centuries, commentaries, expositions and other forms of engagement with $I B P$ dominated international law scholarship. A very large portion of what we now regard as primary sources in international law was originally written as secondary literature on IBP; and virtually all major international law scholars have engaged with $I B P$ since its first appearance in 1625. At historical turning-points, including the demise of the Holy Roman Empire, the fall of Napoleon and the end of both world wars, multinational projects were devoted to restarting international law by reissuing $I B P$ with extensive new commentaries. Each gargantuan attempt to comprehensively restart the project that is public international law were grounded in an attempt to reinterpret $I B P$; and the process invariably produced a plethora of claims for Grotian Moments. What if we could spot the crystallisation of new customs, such as freedom of navigation, armed neutrality or the 'cannon shot rule' for maritime dominion, based on the systematic survey of all the annotations that thousands of statesmen, diplomats, and international law teachers and scholars have left in their copies over the last 400 years?

Thanks to the Deutsche Forschungsgemeinschaft and the Max Planck Institute for Comparative Public Law and International Law, a five-year project began in late 2019 to examine all surviving copies of the first ten editions of $I B P$, with a view to publishing the results in 2025 , the 40oth anniversary of IBP's first appearance. Our project's premise is that despite the enormous literature

34 Richard Cumberland, Philosophical Inquiry, in A Treatise of the Laws of Nature (1672; tr. John Maxwell, ed. Jon Parkin, Indianapolis: Liberty Fund 2005), pp. i-vi, 247-54.

Thomasius' introduction to the first German translation of IBP (1707), translated as 'On the History of Natural Law Until Grotius,' in: Christian Thomasius, Essays on Church, State, and Politics, ed., tr. and intr. by Ian Hunter, Thomas Ahnert, Frank Grunert (Indianapolis IN: Liberty Fund, 2007), pp. 1-48, esp. pp. 43-45. Jean Barbeyrac in Samuel Pufendorf, Of the Law of Nature and of Nations, tr. George Carew (London: Walthoe et al, 1729), I.xxiii-xxiv, and I.xxix.78-79. 
on $I B P$ 's reception and influence, we cannot understand its impact without uncovering the history of $I B P$ as a physical object, with thousands of unpublished annotations arguing or agreeing with the text, and updating and adapting its contents. The census and the annotations also yield hitherto untapped evidence and what came to be accepted as custom, and when. Since current legal analysis and historiography are distinct lanes in what is nonetheless a two-way street, we hope that the improved conception of Grotian Moments that arises from this collection will also inform our understanding of when and how Grotius facilitated Grotian Moments.

This is not to say that the historical applicability of the concept is limited to the Dutchman. Right around the first IBP edition, British lawyers, including Edward Coke and John Selden, who (unfairly) insisted on the separation between the common and Continental law, began to fabricate a legal history to support the claim that Magna Carta was a Grotian Moment. Magna Carta had crystallised, they claimed, not limited claims to freedoms by the aristocracy, but universal rights which, though grounded in divine and natural law and of universal applicability, are nevertheless English in origin and character, turning the nascent British Empire into an agent of global liberty. ${ }^{36}$ Bringing the diagnostic category of Grotian Moments into legal historiography can help us explain how this strange move by activist judges succeeded to a surprising degree, with the language of Magna Carta and other legal instruments directly drawn from it dominating the UDHR, the ICCPR and ICESCSR to this day. ${ }^{37}$

\section{Introductory Afterthoughts and Volume Prologue}

We noted above that naming and understanding have, in principle, no necessary connection. It has long been established in epistemology, however, that

36 Paul D. Halliday, Habeas Corpus: From England to Empire (Cambridge: Harvard University Press, 2010). Somos, 'Selden's Mare clausum'. John Baker, The Reinvention of Magna Carta (Cambridge: Cambridge University Press, 2017). Interestingly, an author in this collection, Dire Tladi, noted in his role as Special Rapporteur on jus cogens that the recognition of peremptory norms also goes back at least to the seventeenth century: A/CN.4/693, First Report of Mr Dire Tladi, SR on the topic of jus cogens. Annual Report of the ILC, ORGA, 71St Sess., Supp. No. 10, UN Doc. A/71/10.

37 On the recent and ongoing dynamic of judicial activism and Grotian Moments, see Frédéric Mégret, 'The "Grotian Style" in International Criminal Justice', infra.

38 George Lakoff, Women, Fire, and Dangerous Things: What Categories Reveal about the Mind (Chicago: University of Chicago Press, 1987), p. 5; and further Hahn and Chater, who argue that " $\mathrm{t}]$ he cognitive system does not treat each new object or occurrence as distinct from and unrelated to what it has seen before: it classifies new objects in terms of concepts which group the new object together with others which have previously been encountered. 
understanding and categorisation, by contrast, are very intimately linked. One may even argue, as Lakoff does, that all conceptual thought is based on categories: 'Categorization', he observes, 'is not a matter to be taken lightly. There is nothing more basic to our thought, perception, action and speech. ${ }^{38}$ To categorise is to understand; to understand is to categorise. ${ }^{39}$ That proposition derives from the work of Plato, who argued that all concepts (and, indeed, all things) are categories defined by an ideal form, from which each actuality will diverge in certain ways. Those things which diverge only a little or which diverge in ways that are not essential to the 'thing-ness' of the ideal may be referred to as being examples of it - notwithstanding that they exhibit differences-while things that diverge more significantly may be different things, conforming to a different ideal. ${ }^{40}$ Every individual apple diverges from the ideal apple to some extent, but nevertheless they remain sufficiently alike to be properly called 'apples'. 'Apple' is a category, defined by its ideal form. ${ }^{41}$

While seeking strictly to define Grotian Moments may be a somewhat pyrrhic endeavour, an enquiry into categorisation offers greater rewards, and animates many of the contributions in this, and its companion, issue. Seeking properly to place Grotian Moments within the matrix of analytical and practical concepts; those of law and those of legal sociology; of addition to or exception from the normal rules of international law: these are debates which promise more enriching insights.

Moreover, the cognitive system also judges whether new objects are similar to old objects': Ulrike Hahn and Nick Chater, 'Concepts and Similarity', in: Koen Lamberts and David Shanks (eds.), Knowledge, Concepts, and Categories (Milton Park: Psychology Press 2013) 43; see also Evan Heit, 'Knowledge and Concept Learning', in: Lamberts and Shanks (eds.), Knowledge, Concepts, and Categories, pp. 7 et seq.

39 Lakoff, Women, Fire and Dangerous Things, pp. $5^{-6}$ et seq.

40 Plato, The Republic, eds. Benjamin Jowett and Tom Butler-Bowdon (Chichester: Capstone, 2012), pp. 356-6o; William A Welton, 'Introduction', in: Plato's Forms: Varieties of Interpretation, ed. by William A. Welton (Lanham: Lexington Books 2002).

41 This is not to imply that one must follow Aristotle in understand categories as essential or predetermined, however. After Kant, it has been generally accepted that categories, though a necessary tool of conceptual understanding, can only explicate the way humans know the world, and not the world itself. Categories are epistemological, and not ontological. Immanuel Kant, Kritik der reinen Vernunft, vol. 1, ed. by Wilhelm Weischedel (Frankfurt: Suhrkamp, 1968), pp. 121-125 (B110-116). In consequence, categories are always socially constructed and operate within a socio-linguistic context, as Bianchi correctly highlights: Andrea Bianchi, 'The Game of Interpretation in International Law: The Players, the Cards, and Why the Game is Worth the Candle', in: Interpretation in International Law, ed. by Andrea Bianchi et al (Oxford: Oxford University Press, 2015), pp. 43-44; see further Lakoff, Women, Fire and Dangerous Things. 
This volume, and its companion issue to be published as issue 43:1 of Grotiana, will explore the concept of Grotian Moments, their historical foundation, and contemporary relevance. Manifold open questions motivate the discussions therein, of which we here highlight a small sub-set:

1. Does the Grotian Moments idea have the character of a legal concept, or is it a sociological concept relating to the functioning of international law?

2. Does the designation of an instance as a Grotian Moment either refer to or precipitate a modification in the rules of recognition of customary international law?

3. Are moments designated retrospectively as Grotian? Could a moment be contemporaneously characterised as such?

4. How momentary are Grotian Moments required to be?

5. Which Grotian Moments have occurred and conversely, which Grotian Moments have failed to occur?

It is with these, and other, questions that the contributors to this double volume will engage. We promise no answers. Instead we have sought to encourage a multiplicity of voices and viewpoints, believing that it is in the debates, disagreements and engagements within these volumes that the most valuable insights will emerge. Such a debate, drawing on various perspectives, employing diverging definitions, and finding differing degrees of merit in the term, is truer to the development of the Grotian Moments concept to date than any order imposed by us could hope to be. Nevertheless, it is our belief that the papers herein do come together to tell a coherent-if never wholly consistent-story of Grotian Moments. We hope that they will stimulate a renewedand appropriately polyphonic — debate on the subject. 